\title{
A Modified Synthesis of Iodoazidoaryl Prazosin
}

\author{
Merritt B. Andrus, 'Sashikumar N. Mettath, Chun, Song \\ Brigham Young University, Department of Chemistry and Biochemistry, C100 BNSN, Provo, UT \\ 84602-5700, USA
}

\section{Supporting Information}

All the compounds are known from the previously reported route. ${ }^{23}$

4,5-Dimethoxyl-2-aminobenzoic Acid (2). A mixture of 4,5-Dimethoxy-2-nitro benzoic acid 1 (5 $\mathrm{g}, 22 \mathrm{mmol}$ ) and $10 \%$ Raney nickel in $25 \mathrm{~mL}$ of 2-propanol was heated at $45{ }^{\circ} \mathrm{C}$ in $\mathrm{H}_{2}$ atmosphere (80 bar). After $5 \mathrm{~h}$, the reaction mixture was filtered, dried under vacuum and recrystallized from EtOH to obtain $3.15 \mathrm{~g}$ of $2(72 \%) . \quad \mathrm{R}_{f}=0.738\left(50 \% \mathrm{MeOH} / \mathrm{CH}_{2} \mathrm{Cl}_{2}\right)$; m.p. $172{ }^{\circ} \mathrm{C} .{ }^{1} \mathrm{H} \mathrm{NMR}$ (DMSO D, $200 \mathrm{MHz}) \delta$ 8.01-8.05 (b, $1 \mathrm{H}), 7.15$ (s, $2 \mathrm{H}), 6.38$ (s, $2 \mathrm{H}), 3.84$ (s, $3 \mathrm{H}), 3.62$ (s, $3 \mathrm{H})$. ${ }^{13} \mathrm{C}$ NMR (DMSO D, $\left.50 \mathrm{MHz}\right) \delta 147.6,106.7,106.4,160.0,105.7,105.3,105.2,56.5,56.1$.

6,7-Dimethoxy-2,4-quinazoline-dione (3). A solution of sodium cyanate $(2.4 \mathrm{~g}, 36.9 \mathrm{mmol})$ in $\mathrm{H}_{2} \mathrm{O}(10 \mathrm{~mL})$ was slowly added to a stirred suspension of $2(2.48 \mathrm{~g}, 15 \mathrm{mmol})$ in a mixture of water $(90 \mathrm{~mL})$ and glacial $\mathrm{AcOH}(1.5 \mathrm{~mL})$ at $35^{\circ} \mathrm{C}$. The reaction mixture was further stirred for $30 \mathrm{~min}$. Sodium hydroxide (26.6 g, $0.67 \mathrm{~mol}$ ) was then added in small proportions to the suspension to give a colorless precipitate. After cooling to $\mathrm{rt}$, the $\mathrm{pH}$ of the suspension was adjusted to $\mathrm{pH} 4$ with concentrated $\mathrm{HCl}$. The precipitate was filtered, washed thoroughly with water and dried at $100{ }^{\circ} \mathrm{C}$ to obtain $3.2 \mathrm{~g}$ of 3 (97\%). $\mathrm{R}_{f}=0.732\left(20 \% \mathrm{MeOH}\right.$ in $\left.\mathrm{CH}_{2} \mathrm{Cl}_{2}\right) ; \operatorname{mp} 278{ }^{\circ} \mathrm{C} ;{ }^{1} \mathrm{H} \mathrm{NMR}\left(\mathrm{DMSO} \mathrm{D}_{6}\right.$, 
$200 \mathrm{MHz}) \delta 7.24(\mathrm{~s}, 1 \mathrm{H}), 7.04(\mathrm{~s}, 1 \mathrm{H}), 6.98\left(\mathrm{~s}, 2 \mathrm{H}\right.$, amino-H), $3.94(\mathrm{~s}, 3 \mathrm{H}), 3.86(\mathrm{~s}, 3 \mathrm{H}) .{ }^{13} \mathrm{C}$ NMR (DMSO D, 50 MHz) $\delta 168.5,164.5,106.9,106.7,160.3,105.7,105.3,105.2,57.5,56.7$.

2.4-Dichloro-6,7-Dimethoxyquinazoline (4). A mixture of 3 (3.34 g, $15.05 \mathrm{mmol}), 10 \mathrm{ml}(0.107$ $\mathrm{mol})$ of $\mathrm{POCl}_{3}$ and $1 \mathrm{~mL}(12.8 \mathrm{mmol})$ of $\mathrm{N}, \mathrm{N}$-dimethylaniline was refluxed for $4.5 \mathrm{~h}$, cooled, and allowed to stir overnight at rt. The mixture was then added to $70 \mathrm{~mL}$ of ice water, and the resultant precipitate was filtered, washed with water and dried to obtain $2.67 \mathrm{~g}$ of $4(68 \%) . \mathrm{R}_{f}=0.573(20 \%$ $\mathrm{MeOH}$ in $\mathrm{CH}_{2} \mathrm{Cl}_{2}$ ); mp $156{ }^{\circ} \mathrm{C} ;{ }^{1} \mathrm{H}$ NMR (DMSO D, $\left.200 \mathrm{MHz}\right) \delta 7.21(\mathrm{~s}, 1 \mathrm{H}), 7.18(\mathrm{~s}, 1 \mathrm{H}), 3.96$ $(\mathrm{d}, 6 \mathrm{H}) .{ }^{13} \mathrm{C}$ NMR $\left(\mathrm{DMSO} \mathrm{D}_{6}, 50 \mathrm{MHz}\right) \delta 168.7,164.5,108.7,108.4,108.0,107.7,107.3,107.2$, $58.5,56.1$.

2-chloro-4-amino-6,7-dimethoxyquinazoline (5). A solution of 4 (15 g, $8 \mathrm{mmol})$ in $400 \mathrm{~mL}$ of THF, was saturated with anhydrous $\mathrm{NH}_{3}$, and stirred for $44 \mathrm{~h}$ at $\mathrm{rt}$. The precipitate that was formed was collected and recrystallized from $\mathrm{MeOH}$, to obtain $9.51 \mathrm{~g}\left(68 \%\right.$ yield) of $\mathbf{5}, \mathrm{R}_{f}=0.52(20 \%$ $\mathrm{MeOH} / \mathrm{CH}_{2} \mathrm{Cl}_{2}$ ) mp $301{ }^{\circ} \mathrm{C},{ }^{1} \mathrm{H}$ NMR (DMSO D, $\left.200 \mathrm{MHz}\right) \delta 7.95-8.05$ (b 2H), $7.61(\mathrm{~s}, 1 \mathrm{H})$, $7.05(\mathrm{~s}, 1 \mathrm{H}), 3.91(\mathrm{~s}, 3 \mathrm{H}), 3.85(\mathrm{~s}, 3 \mathrm{H}) .{ }^{13} \mathrm{C}$ NMR (DMSO D, $\left.50 \mathrm{MHz}\right) \delta 152.1,145.7,106.7$, $106.1,105.8,104.7,104.3,104.2,58.5,56.1$.

[4 -(Piperazine-1-carbonyl)-phenyl]-carbamic acid tert-butyl ester (7). 1,1Carbonyldiimidazole $(0.867 \mathrm{~g}, 5.34 \mathrm{mmol})$ of was added to Boc-protected p-amino benzoic acid $(1.0 \mathrm{~g}, 4.22 \mathrm{mmol})$ in $10 \mathrm{~mL}$ of DMF and stirred at $\mathrm{rt}$ for $1 \mathrm{~h}$. Anhydrous piperazine $(0.963 \mathrm{~g}, 11.12$ mmol) was then added to this solution and the reaction mixture was stirred at rt overnight. A white precipitate formed which was washed with cold water and dried under vacuum to obtain $0.650 \mathrm{~g}$ (51\%) of the title compound 7. $\mathrm{R}_{f} 0.40\left(30 \% \mathrm{CH}_{3} \mathrm{OH}\right.$ in $\left.\mathrm{CH}_{2} \mathrm{Cl}_{2}\right) .{ }^{1} \mathrm{H} \mathrm{NMR}\left(\mathrm{CDCl}_{3}, 300 \mathrm{MHz}\right) \delta$ $7.40(\mathrm{~m}, 4 \mathrm{H}), 6.65(\mathrm{~s}, 1 \mathrm{H}), 3.60(\mathrm{~b}, 4 \mathrm{H}), 2.83$ (b, 4H), 1.44 (s, 9H). MS (EI+) 305 (M, 100).

\footnotetext{
"Address for correspondence. Telephone 801 422-8171. E-mail: mbandrus@ chemdept.byu.edu
} 


\section{\{4-[4-(4-Amino-6,7-dimethoxy-4a,5-dihydro-quinazolin-2-yl)piperazine-1-carbonyl]-phenyl\}-} carbamic acid tert butyl ester (8) The reaction mixture containing tert-butyl alcohol (125 mL), 2chloro-4-amino-6,7-dimethoxyquinazoline 5 (1.0 g, $4.81 \mathrm{mmol})$ and compound 7 (1.6 g, 5.30 mmol) was refluxed for $24 \mathrm{~h}$. The reaction was cooled and rotary evaporated to dryness. The solid residue was chromatographed on silica gel using $10 \%$ methanol in methylene chloride as elutant to obtain $1.245 \mathrm{~g}(75 \%)$ of the desired compound 8. $\mathrm{R}_{f} 0.33\left(10 \% \mathrm{CH}_{3} \mathrm{OH}\right.$ in $\left.\mathrm{CH}_{2} \mathrm{Cl}_{2}\right) .{ }^{1} \mathrm{H}$ NMR (DMSO D, $300 \mathrm{MHz}) 7.52$ (s, 1H), 7.46 (s, 1H), $7.36(\mathrm{~d}, 2 \mathrm{H}), 7.26$ (b, 2H), 6.67 (s, 1H), 3.83 (s, $3 \mathrm{H}), 3.78$ (s, 3H), $3.76(\mathrm{~b}, 4 \mathrm{H}), 3.51(\mathrm{~b}, 4 \mathrm{H}) . \mathrm{MS}\left(\mathrm{EI}^{+}\right) 508(\mathrm{M}, 100)$

[4-(4-Amino-6,7-dimethoxy-quinzaloin-2-yl)]-(4-amino-phenyl)-methanone. Compound 8 (280 $\mathrm{mg}, 0.550 \mathrm{mmol}$ ) was stirred in $11.0 \mathrm{~mL}$ of $4 \mathrm{~N} \mathrm{HCl} /$ dioxane at $0{ }^{\circ} \mathrm{C}$. for $2 \mathrm{~h}$. The reaction was concentrated in vacuum to give a residue which was successively washed with ethyl acetate, ether and ethanol. The resulting solid was suspended in ethanol and the suspension was heated on a steam bath, cooled to rt, and filtered to obtain $203 \mathrm{mg}(77 \%)$ of the title compound. ${ }^{1} \mathrm{H}$ NMR (DMSO D $300 \mathrm{MHz}) \delta 7.39(\mathrm{~s}, 1 \mathrm{H}) 7.14(\mathrm{~b}, 1 \mathrm{H}), 7.11(\mathrm{~d}, 2 \mathrm{H}), 6.72(\mathrm{~s}, 1 \mathrm{H}), 6.53(\mathrm{~d}, 2 \mathrm{H}), 5.43(\mathrm{~b}, 1 \mathrm{H}), 3.78$ (s, 3H), $3.74(\mathrm{~s}, 3 \mathrm{H}), 3.71(\mathrm{~s}, 3 \mathrm{H}), 3.51(\mathrm{~b}, 4 \mathrm{H}) . \mathrm{MS}\left(\mathrm{EI}^{+}\right) 408(\mathrm{M}-2 \mathrm{HCl}, 100)$

\section{2-[4-(4-Amino-3-iodobenzoyl)piperazin-1-yl]-4-amino-6,7-dimethoxyquinazoline (9) A} mixture of the dichloride salt from above $(500 \mathrm{mg}, 1.03 \mathrm{mmol})$, benzyltrimethylammonium dichloroiodate $(430 \mathrm{mg}, 1.23 \mathrm{mmol})$ and $\mathrm{CaCO}_{3}(278 \mathrm{mg}, 2.78 \mathrm{mmol})$ in $11.7 \mathrm{~mL}$ of $\mathrm{CH}_{2} \mathrm{Cl}_{2}$ and $8.0 \mathrm{ml}$ of methanol was stirred overnight at $\mathrm{rt}$ for $16 \mathrm{~h}$. The solution was filtered, washed with saturated $\mathrm{Na}_{2} \mathrm{~S}_{2} \mathrm{O}_{3}$ solution and water and dried over sodium sulfate. The solid obtained was chromatographed on silica gel using $10 \%$ methanol in methylene chloride as elutant to obtain 520 mg $\left(80 \%\right.$ yield) of the desired product 9. $\mathrm{R}_{f} 0.36\left(10 \% \mathrm{CH}_{3} \mathrm{OH}\right.$ in $\left.\mathrm{CH}_{2} \mathrm{Cl}_{2}\right) .{ }^{1} \mathrm{H} \mathrm{NMR}\left(\mathrm{CDCl}_{3}, 300\right.$ $\mathrm{MHz}) \delta 7.81(\mathrm{~d}, 1 \mathrm{H}), 7.31(\mathrm{~s}, 1 \mathrm{H}), 6.92(\mathrm{~s}, 1 \mathrm{H}), 6.78(\mathrm{~s}, 1 \mathrm{H}), 5.12(\mathrm{~s}, 2 \mathrm{H}), 4.26(\mathrm{~s}, 2 \mathrm{H}), 3.98(\mathrm{~s}$, $3 \mathrm{H}), 3.94(\mathrm{~s}, 3 \mathrm{H}), 3.7-3.91(\mathrm{~m}, 8 \mathrm{H})$; HRMS: calculated for $\mathrm{C}_{21} \mathrm{H}_{23} \mathrm{O}_{3} \mathrm{~N}_{6} \mathrm{I} 534.0877$ found 534.0881

Iodoazidoarylprazosin Compound $9(100 \mathrm{mg}, 0.19 \mathrm{mmol})$ was dissolved in $10 \mathrm{~mL}$ of $8 \mathrm{~N}$ acetic acid and cooled to $0{ }^{\circ} \mathrm{C}$. A $5 \%$ aqueous solution of $\mathrm{NaNO}_{2}$ was added to this solution and the 
solution was stirred for $5 \mathrm{~min}$. A $5 \%$ aqueous solution of $\mathrm{NaN}_{3}(0.25 \mathrm{~mL})$ was then added and the reaction was allowed to warm for $5 \mathrm{~min}$. The reaction was again cooled to $0{ }^{\circ} \mathrm{C}$, neutralized with 10 $\%$ aqueous $\mathrm{NaOH}$, and extracted with $\mathrm{CH}_{2} \mathrm{Cl}_{2}$. The organic layer was dried over $\mathrm{Na}_{2} \mathrm{SO}_{4}$ and evaporated. The crude yellow oil was solidified by the addition of ether and evaporation in vacuo. The solid was purified by radial chromatography using $10 \%$ methanol in dichloromethane as elutant to obtain $72 \mathrm{mg}$ (65\%) iodoarylprasozin. ${ }^{1} \mathrm{H} \mathrm{NMR}\left(\mathrm{CDCl}_{3}, 300 \mathrm{MHz}\right) \delta 7.9(\mathrm{~d}, 1 \mathrm{H}) 7.5(\mathrm{~m}$, 1H), 7.19 (d, $1 \mathrm{H}), 6.92(\mathrm{~s}, 1 \mathrm{H}), 5.16(\mathrm{~s}, 2 \mathrm{H}), 3.99$ (s, 3H), 3.95 (s,3H), 3.40 - 4.20 (m, 8H). HRMS : calculated for $\mathrm{C}_{21} \mathrm{H}_{21} \mathrm{O}_{3} \mathrm{~N}_{8} \mathrm{I}$ 560.08, Found : 560.0779. IAAP was further purified by reverse phase HPLC (C18) using 60\% acetonitrile/water and a flow rate of $1.0 \mathrm{~mL} / \mathrm{min}$ (5.9 $\mathrm{min})$.

\section{Procedure for Palladium-Catalyzed Animation Reactions:}

Using imidazolium 10 as ligand: To a flame dried flask under nitrogen were added 4-amino-6,7dimethoxy-2-chlorolquinazoline 5 (23.9 mg, $0.1 \mathrm{mmol})$, amine nucleophile $\mathrm{NuH}(0.8 \mathrm{mmol})$, and sodium tert-butoxide (9.6 mg, $0.10 \mathrm{mmol})$, followed by $\mathrm{Pd}(\mathrm{OAc})_{2}(0.45 \mathrm{mg}, 0.002 \mathrm{mmol}, 2 \mathrm{~mol} \%)$ and N,N-bis-(2,6-diisopropyl)dihydroimidazolium chloride 10 (0.85 mg, $0.002 \mathrm{mmol}, 2 \mathrm{~mol} \%)$ in anhydrous THF $(2 \mathrm{~mL})$. The resulting suspension was stirred at $\mathrm{rt}$ for $12 \mathrm{~h}$. To the reaction mixture was added ethyl acetate $(10 \mathrm{~mL})$. The ethyl acetate solution was washed 3 times with aqueous brine and dried over anhydrous magnesium sulphate. The solvent was concentrated by rotary evaporation and the crude material was purified by silica gel chromatography using methanol/methylene chloride (2-10\%). The known compounds 11, with the isolated yields indicated (Table 1), were characterized by the individual data shown below.

Using tri-tert-butylphosphine as ligand: To a flame dried flask under nitrogen were added 4Amino-6,7-dimethoxy-2-chlorolquinazoline 5 (23.9 mg, $0.1 \mathrm{mmol})$, amine nucleophile $\mathrm{NuH}(0.8$ $\mathrm{mmol}$ ), and sodium tert-butoxide (14.4 mg, $0.15 \mathrm{mmol})$, followed by $\mathrm{Pd}(\mathrm{OAc})_{2}(0.45 \mathrm{mg}, 0.002$ mmol, $2 \mathrm{~mol} \%)$ and tri-tert-butylphosphine $(0.34 \mathrm{mg}, 0.002 \mathrm{mmol}, 2 \mathrm{~mol} \%)$ in anhydrous oxylene $(2 \mathrm{~mL})$. The resulting suspension was stirred at reflux for $36 \mathrm{~h}$. The solution was allowed to 
cool and to the reaction mixture was added ethyl acetate $(10 \mathrm{~mL})$. The ethyl acetate solution was washed 3 times with aqueous brine and dried over anhydrous magnesium sulphate. The solvent was concentrated by rotary evaporation and the crude material was purified by silica gel chromatography using methanol/methylene chloride (2-10\%). The known compounds 11, with the isolated yields indicated (Table 1), were characterized by the individual data shown below.

Using 4,5-dehydro-10 as ligand: To a flame dried flask under nitrogen were added 4-Amino-6,7dimethoxy-2-chlorolquinazoline 5 (23.9 mg, $0.1 \mathrm{mmol})$, amine nucleophile $\mathrm{NuH}$ (0.8 mmol), and sodium tert-butoxide (9.6 mg, $0.10 \mathrm{mmol})$, followed by $\mathrm{Pd}(\mathrm{OAc})_{2}(0.45 \mathrm{mg}, 0.002 \mathrm{mmol}, 2 \mathrm{~mol} \%)$ and N,N-bis-(2,6-diisopropyl)-imidazolium chloride (0.85 mg, $0.002 \mathrm{mmol}, 2 \mathrm{~mol} \%)$ in anhydrous THF ( $2 \mathrm{~mL})$. The resulting suspension was stirred at $\mathrm{rt}$ for $12 \mathrm{~h}$. To the reaction mixture was added ethyl acetate $(10 \mathrm{~mL})$. The ethyl acetate solution was then washed 3 times with aqueous brine and dried over anhydrous magnesium sulphate. The solvent was concentrated by rotary evaporation and the crude material was purified by silica gel chromatography using methanol/methylene chloride (2-10\%). The known compounds 11, with the isolated yields indicated (Table 1), were characterized by the individual data shown below.

4-Amino-6, 7-dimethoxy-2-piperazinylquinazoline: $R_{f}: 0.55$ (DCM: $\mathrm{MeOH}: \mathrm{NH}_{4} \mathrm{OH} / 75: 23: 2$ ); ${ }^{1} \mathrm{H}$ NMR (DMSO) $\delta 7.78(\mathrm{~s}, 1 \mathrm{H}), 7.43(\mathrm{~s}, 1 \mathrm{H}), 7.18$ (s, 1H), 6.93 (s, 1H), 5.24 (Broad, 1H), 3.90 (s, $3 \mathrm{H}), 3.86(\mathrm{~s}, 3 \mathrm{H}), 3.79-3.34(\mathrm{~m}, 8 \mathrm{H}) ;{ }^{13} \mathrm{C}$ NMR (DMSO) $\delta 170.1$ (s, 1H), 156.8 (s), $152.4(\mathrm{~s}), 146.1$ (s), $141.2(\mathrm{~s}), 140.3(\mathrm{~s}), 128.6(\mathrm{~s}), 100.3$ (s), 71.7 (s), 56.2 (s), 55.3 (s), 41.8 (s), 41.3 (S), 38.6 (s); MS (EI) 290.

4-Amino-6, 7-dimethoxy-2-morpholinylquinazoline: $R_{f}$ : 0.45 (DCM: $\mathrm{MeOH}: \mathrm{NH}_{4} \mathrm{OH} / 75: 23: 2$ ); ${ }^{1} \mathrm{H}$ NMR (DMSO) $\delta 7.69(\mathrm{~s}, 1 \mathrm{H}), 7.38(\mathrm{~s}, 1 \mathrm{H}), 7.17(\mathrm{~s}, 1 \mathrm{H}), 6.95(\mathrm{~s}, 1 \mathrm{H}), 3.88(\mathrm{~s}, 3 \mathrm{H}), 3.83(\mathrm{~s}, 3 \mathrm{H})$, 3.64-3.02(m, 8H); ${ }^{13} \mathrm{C}$ NMR (DMSO) $\delta 178.0(\mathrm{~s}, 1 \mathrm{H}), 171.2(\mathrm{~s}), 164.4(\mathrm{~s}), 153.8(\mathrm{~s}), 147.2(\mathrm{~s})$, $143.5(\mathrm{~s}), 130.6(\mathrm{~s}), 99.8(\mathrm{~s}), 77.4(\mathrm{~s}), 76.8(\mathrm{~s}), 74.6(\mathrm{~s})$, 72.5 (s), 55.3 (s), 54.6 (S); MS (EI) 291. 
4-Amino-6, 7-dimethoxy-2-imidazolinyl-quinazoline: $R_{f}: 0.50$ (DCM: $\mathrm{MeOH}: \mathrm{NH}_{4} \mathrm{OH} / 75: 23: 2$ ) ${ }^{1} \mathrm{H}$ NMR (DMSO) $\delta 8.01(\mathrm{~s}, 1 \mathrm{H}), 7.82(\mathrm{~s}, 1 \mathrm{H}), 7.80(\mathrm{~s}, 1 \mathrm{H}), 7.69(\mathrm{~s}, 1 \mathrm{H}), 7.38(\mathrm{~s}, 1 \mathrm{H}), 7.17(\mathrm{~s}, 1 \mathrm{H})$, 6.95 (s, 1H), 3.90 (s, 3H), 3.87 (s, 3H); ${ }^{13} \mathrm{C}$ NMR (DMSO) $\delta 176.2$ (s, 1H), 164.2 (s), 155.4 (s), 148.8 (s), 146.2 (s), 141.4 (s), 130.4 (s), 128.6 (s), 126.5 (s), 125.8 (s), 99.5 (s), 57.6 (s), 55.3 (s); MS (EI) 272. 